\title{
FORMATION OF A NEW PARADIGM OF INNOVATIVE TECHNOLOGICAL DEVELOPMENT
}

\section{NATALIYA APATOVA, SVETLANA GERASIMOVA, AMINA ZHAROVA, TATYANA BUGAEVA \& SEMYON REUS}

V.I. Vernadsky Crimean Federal University, 4 Vernadskogo Avenue, Simferopol, Republic of Crimea, 295007, Russia \begin{abstract}
The article is devoted to the study of the actual scientific and practical problems of the macroeconomic theory of innovative processes that have a significant impact on technological development and the formation of a new paradigm and ensuring the stability of the development of high-tech industries. The following tasks completed to achieve this goal: first, the evaluation a scientific discussion on the formation of an innovative technological paradigm; second, the determination the role of investment in innovative activity; third, the formation approaches to the creation of a paradigm. The evaluation of a scientific discussion was according the state policy of innovative development, the fundamental differences between the theoretical arguments of the advocates of neoliberalism, liberalism and classicism. There is analyzing the position of economists supporting the monetarist theory and evaluating it from the point of view of an effective regulator. The qualitative changes in the institutional framework and timely, high quality transformational processes in the public administration system determinate innovative technological development, which also depends on the selected vector of economic theory, based on knowledge and practical experience. We define the innovative technological paradigm as the basis for evolutionary transformations, methodology, technologies, the general strategy of socio-economic development and the formed approaches. The state policy of innovative technological development is a methodological basis, which found on the theory of economic development using various theories to attract investment in innovation. The entire historical development of the Russian economy proves the effectiveness of innovations in technological development and the future directly dependents on the fundamental prerequisites for the effective use of new knowledge.
\end{abstract}

KEYWORDS: Innovative Development; Technological Development; Paradigm; Resource Potential

Received: May 23, 2020; Accepted: Jun 13, 2020; Published: Jul 24, 2020; Paper Id.: IJMPERDJUN2020438

\section{INTRODUCTION}

A new paradigm of the Russian economy forms in the context of modern accelerated development of the entire world economy. These processes have a base the strategy of innovative development, the introduction of new hightech technologies, and the constant monitoring of markets for goods and services in order to search for future transformations that are the first to find unexpected solutions. To ensure future socio-economic development, it is necessary for state to mobilize resource potential. Innovative transformation is in the forefront in the context of the modern transition to innovative economic development, and its basis is composed of cognitive, information and communication, nanotechnologies, biotechnologies, which form a new development trajectory for the sixth technological structure. These conditions for the formation of the new innovative paradigm require specialists of a new formation who possess many competencies for a successful transition to a new reality. 
Qualitative changes in the system of institutional foundations and modern transformational processes in the public administration system determine the development of the state. In the Russian economy, public policy attaches great importance to monetarist and Keynesian theory, which under different conditions of economic development can give different results, but the effectiveness of their application can have a contradictory result. Monetarist theory has a cyclical character; it lies in many points of the Strategy for the socio-economic development of the Russian Federation, targeted state programs to ensure the socio-economic development of society in specific situations. However, new institutional and technological conditions require a new economic theory that will allow for economic growth.

The purpose of this article is a theoretical review of the formation of a paradigm of innovative technological development.

\section{LITERATURE REVIEW}

The modern world lives in times of great challenges and previously unknown trends that enhance the unpredictability of socio-economic development in future periods. The choice of the theory of economic development, which discuss by economists and manufacturing practices that form the system of market relations in the Russian Federation, significantly affects the formation of a new innovative technological paradigm based on the market and market relations. The emergence of market relations in the Russian economy dates back to 1991, and it was time to need determine the theoretical basis for stabilization state policy. The government chose the monetarist theory in the process of liberal transformations in the Russian economy. A characteristic feature of this theory is the limitation of the money supply in circulation, but this policy at that time was justified and relevant [1].

At the present stage of innovative development, the creation of effective mechanisms in the financing system bases to the totality of financial institutions; the linking system of these elements not been fully studied. Priority directions of state policy depend on the chosen vector of economic theory based on knowledge and practical experience [2]. State policy in the Russian economy attaches great importance to monetarist and Keynesian theory, which under different conditions of economic development can produce different results and the effectiveness of their application, can have a contradictory result.

Monetarist politics was relevant and timely in the 90s; it was a period of the emergence of market relations in all states of the former Soviet Union, to which Russia belonged. At the beginning of market transformations, demand inflation prevailed and the population had an excess of cash. Public policy first encountered this phenomenon and adopted the recommendations of the International Monetary Fund in accordance with the concept for countries with developing economies, which included liberalization and privatization. The authors of the proposed concept believed that stabilization should occur, if the strict destructive methods use to limit the money supply. In our opinion, this radical liberalization did not create a competitive environment before privatization, but still maintained a high level of monopolization of the economy, which eventually led to hyperinflation, which in 1992 was $2510 \%$, according to some reports, and in 1993, it was $840 \%$. Real cash incomes of citizens halved, citizens' savings in banks and insurance companies practically destroyed during 1991-1992 because of galloping inflation.

The tough monetary policy pursued has made it possible to reduce aggregate demand by lowering consumer, investment, and government spending. By 1993, inflation began to decline, and the non-monetary macroeconomic and microeconomic foundations of inflationary processes began to appear in this decrease. The basics of these processes 
include the following components: first, outstripping growth in prices for material resources; second, high level of interest and tax rates; third, monopolization of the economy; forth, monetary methods that work effectively with increased demand in the context of inflation of production costs, which are making up the factors of its self-development. The growth of unemployment intensified and enterprises were unable to fulfill their payment obligations due to the contradictory causes of inflationary processes, which provoked a decline in production, an increase in average costs and a reduction in investment [3]. This state of economic development requires a change in public economic policy aimed at changing the system of anti-crisis measures that are able to maintain their inertia for some time. At the same time, the government continued to pursue a monetarist policy, which objectively led to a reduction in investment in fixed assets and the aggregate demand of the economy until simple reproduction [4].

The insolvency of industrial and agricultural enterprises contradicted the development of a market economy, financial system and the theory of monetary relations. It should be borne in mind that was a certain dependence of the "emerging" market Russian economy "on the conjuncture of world commodity prices for fuel and energy and raw materials" has manifested itself [1, p. 8]. This situation in 1996-1999 had a result in rising inflation, incomes decreased, Russian society was overwhelmed by unemployment, the streets turned into continuous markets, and debts to employees formed. It seemed to people that the state lives in its own specific world and follows its own path, unknown to the population. The Russians survived as best they could, and the state could not decide on the transition in their policies to Keynesian theory and theory of supply. After the 1998 financial crisis, in early 2000, public policy began to use Keynesian theory, but it increases in prices for imported goods. On the one hand, population incomes decreased, but on the other, Russian producers began to form their competitive advantages. As a result, Keynesian theory had a positive impact on the development of industrial production, which provided a certain economic growth. However, these were temporary phenomena [5].

The Bank of Russia and the Government of the Russian Federation support and again apply the monetarist theory, which has priority in Russian economic policy, but this affects the slowdown in the growth of aggregate demand. Monetary policy of the Central Bank of the Russian Federation applies high key interest rates. One of the founders of the neoKeynesian theory of dynamics R.F. Harrod [6] proved that lowering the interest rate "serves as a prerequisite for the development of the economy at a pace consistent with its potential capabilities." Therefore, interest rate reduction is one of the most important conditions for economic development. A negative factor for the Russian economy was the increase by the Government of the Russian Federation of the interest rate of value added tax from 18 to $20 \%$.

The development of Russia in the conditions of the sixth technological level is impossible without the development of a digital economy, infrastructure, innovative development, institutional environment, developed social institutions that form a new paradigm of innovative technological development [7].

The main role in economic development plays the state economic policy, which implemented in the Development Strategy of the Russian Federation until 2030. This development of a knowledge-based economy depends on the choice of direction of economic theory. The sections of Keynesian economics, monetarism and the theory of economics of supply have the greatest applied value. Their implementation in the process of forming a digital economy acquires features that are associated with practical experience [8,9].

The innovation system of the national economy has significant features and this is the reason for the implementation of the state macroeconomic policy, therefore it is the basis for the study of the modern paradigm of 
innovative technological development [10]. We evaluate innovative solutions to investments and obtain effective results, considering innovative development as a socio-economic concept. Innovation is of the utmost importance. in a high-tech economy, they are changing the structure of the economy to provide a technological breakthrough. Many scientists developed innovative theories, reflecting in them the dynamic, evolutionary direction of economic development [11, 12]. Joseph Alois Schumpeter describes and substantiates that transformational processes are cyclical. The innovative development of high technology plays a leading role in competitiveness and characterized by a wide scope, based on complex structural elements that have many approaches for effective interaction $[13,14,15]$.

\section{FORMATION OF APPROACHES TO ACCELERATE THE DEVELOPMENT OF SCIENCE AND TECHNOLOGY}

Certain theoretical approaches ensure the formation of a new innovative technological paradigm, and a post-industrial society develops on this base. The formation of this paradigm takes its roots from the change of reproduction processes for the introduction of innovations that can produce through the mechanism of introducing high technology into production processes [16-19]. There are many industries in the Russian economy that are innovating in all areas of activity: education, manufacturing processes, agriculture, medicine, nanotechnologies and biotechnologies, the financial sector, the tourism industry, management and others. The need of society to accelerate the development of science and technology ensures the formation of innovative technological development. These processes affect the speed of innovative development, and at the peak of a certain cycle of the innovation wave, a change in the technological mode. The venture business is the basis of the innovative system and the knowledge economy in developed countries and it determines their development. In Russia, the basis for the formation of a model of innovative development is the market for high-tech products. The current situation in the global economy has contributed to the national economy refocusing on import substitution in many sectors of the economy, including biomedicine. This direction is promising. Innovations based on the knowledge economy play a huge role in ensuring the competitiveness of the sectoral economy, business entities, and regional development [20-23].

The formation of a new paradigm of innovative technological development occurs with the help of classical and applied approaches. From the standpoint of macroeconomic theory, an analysis of the discussions of the points of view of domestic and foreign economists carried out, the subject of which was different views on the above issue, the choice and application of economic theory. The authors of the study studied the scientific dialogues of macroeconomists, the arguments of which differ fundamentally with respect to innovation policy, technological development, but they all focus on increasing funding for science and technology [24-29]. Summing up, we can affirm that the applied value of macroeconomic theory based on Keynesian, monetarist theory, as well as on the theory of supply economics, in which a number of features based on practical experience arise. This helps to produce and maintain balance through the formation of various approaches in the process of forming a digital economy. We note that it is the approaches to the formation of an innovative technological paradigm not defined as an economic category; they base on complex structural elements that have many links for effective interaction [30-36].

Consider the classic approach to the innovative technological paradigm. It can and should be as an economic category of economic activity based on new technologies, methods and approaches, the ability to generate, produce and promote competitive products on the market, with the aim of creating a fundamental innovative society that can create new qualities and find new sources of resources, carry out transformation institutional foundations and social institutions. 
Because of innovative technological transformation, a new cycle begins and a starting position for creation of a macroeconomic theory of innovations, as a synthesis of cycle theory, models of economic growth and the formation of a new trajectory of innovative technological development. This allows us to formulate a new paradigm and define its clear guidelines.

The basis of the second applied approach reveals a more expanded content of the development of an innovative technological paradigm. According to the authors, this is part of the economic, knowledge-intensive, production, social, cultural relations directly related to the production system, implementation, distribution and exchange. The formation of the entire chain of a closed industrial production cycle, a cycle with the release of competitive products focuses on consumer markets for goods and services.

\section{ENHANCING THE ROLE OF INVESTMENT IN INNOVATION AND KNOWLEDGE-BASED INDUSTRIES}

The theoretical foundations of the development of macroeconomic science based on the tenets of economic development, including the principles of the digital economy [2, 37, 38, 39]. The development of the economy based on methodology, methods, technologies, and a general strategy for socio-economic development. Public policy based on the theory of economic development using various theories to attract investment in innovation. One of the main factors that have affected structural changes in the Russian economy over the past five years is the increasing role of investment and innovation. These changes can grouped into two main groups: the first relates to the investment and innovation perception of enterprises and organizations, the other relates to state policy. In these two groups, the problems of choosing strategic priorities, mechanisms and directions for investing financial resources, effective forms of cooperation with other participants in the innovation process are relevant. The identified problems set the tasks of forming new, as well as complete modernization of old social, economic and political institutions.

An important link in the budgeting system is off-budget innovative funds, with the help of which redistribution of national income in favor of financing investment and innovative activities occurs. These funds use in the processes of expanded reproduction.

In the first quarter of 2019, the Russian economy again showed a $1.3 \%$ GDP growth amid a deficit in aggregate demand (according to the Ministry of Economic Development of the Russian Federation). Final demand has recovered, structural changes in the economy have begun, acceleration of GDP growth rates to $1.7 \%$ has begun, and GDP growth by 3.1-3.2\% expect in 2020. Inflation in 2019 amounted to 3.8\%, as of August 26, 2019, oil prices consolidated below the level of $\$ 60$ per barrel, which corresponds to the current planned level, the ruble exchange rate returned to its fundamental values.

The Russian economy intends in 2020-2021 to change the phases of credit cycles under the influence of monetarist economic theory; after the contribution of consumer credit to the growth of final demand of 1.7 trillion. Rubles, all household consumption this year will amount to $3.3 \%$. A sharp slowdown in consumer demand planned to $0.6 \%$ there will be an increase in the disinflation trend. Inflation in 2020 will fall below 3\%; under the influence of monetary policy, consumer credit can replace by mortgage and corporate loans. Given the above, there is a plan to expect an increase in real incomes of the population against the background of an increase in interest payments and a weakening of aggregate demand as of 2019. In 2020, aggregate demand will be $1.5 \%$ in connection with economic growth and investment activity. 
The main driver of the economic growth of the Russian economy will be investments, which according the forecasts increase by $5 \%$ in 2020 . This will be simultaneously with weakening consumer demand and the instability of the global economy [40].

The tense geopolitical situation that has developed in the world has become an incentive for a quick reorientation of the entire educational sphere of school and university education, distance learning rapidly introduced. Under the influence of globalization processes, a reorientation of the national economy takes place, based on the strategy of import substitution in many areas of activity [41, 42]. The creation of new products that consumers are already waiting on the marketsж pushes for technological innovation, the development of new approaches and identifying ways to achieve the goal and objectives. Consider the promising areas of technological development, which include: air transport; automobile transport; neuro communications; sea transport; development of biomedicine; food industry; financial sphere; power engineering; state security (Figure 1 - Compiled by the authors).

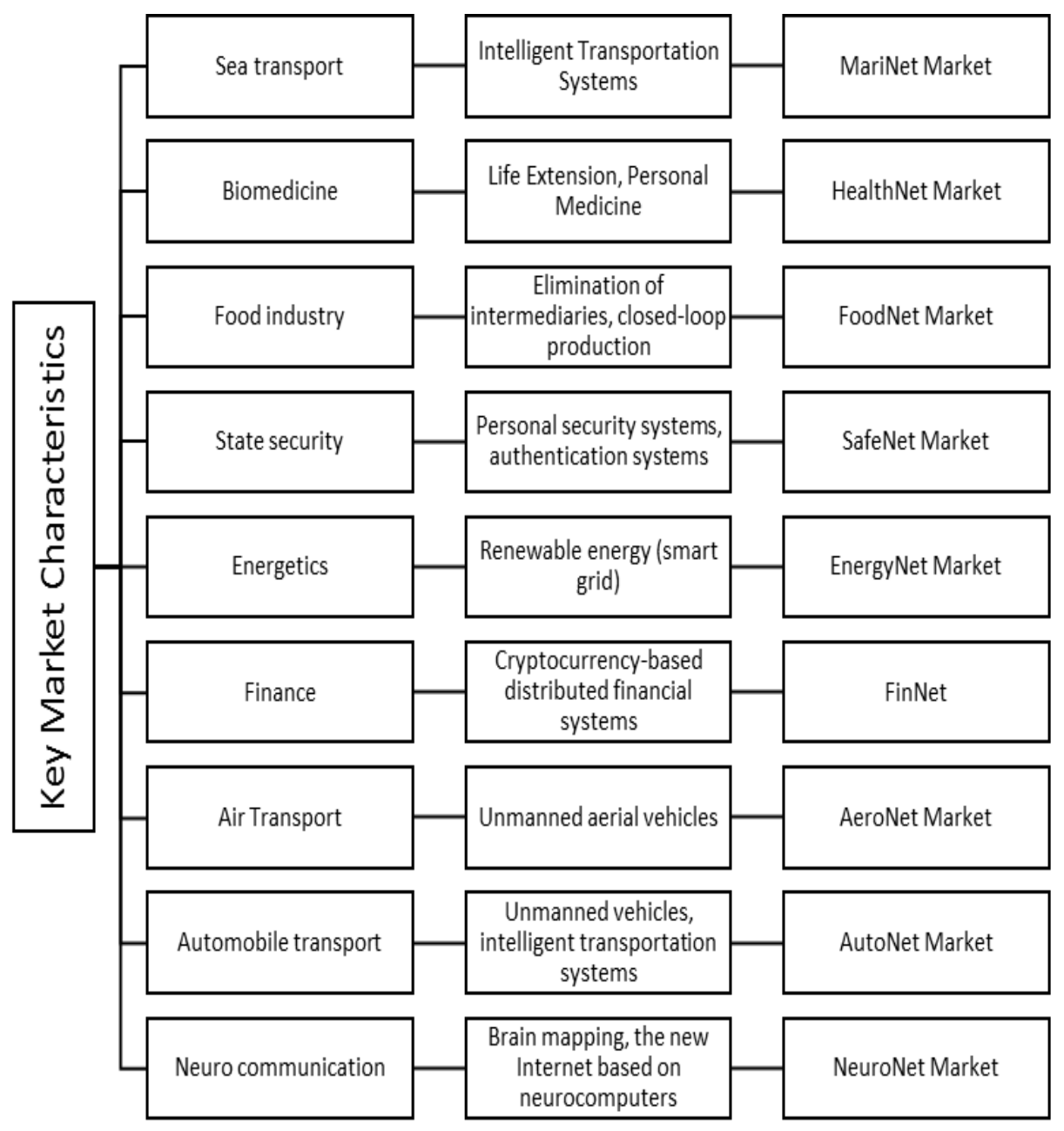

Figure 1: Promising Areas of Technological Development.

Seven Russian innovations will change the future. For many years, Russia not considered a technological state, much less an innovative world leader, despite one of the world's strongest scientific and technical schools. However, the situation is changing: in 2019, there are already at least seven results of this in the global innovation index for 2019. Russia is located on 46th place from 129 countries of the world. At the same time, experts acknowledge that our country is one of the leaders in activity in the field of innovation. 
Note high-tech among low- and middle-income countries. Russia is among the leaders in the world in terms of the intensity of costs for innovative technologies by industry enterprises. Domestic industrial enterprises invest in innovation more than other branches; the service sector is in second place, followed by agriculture and construction. It is possible that Russian scientists and entrepreneurs will determine soon the situation in the global high-tech market.

Which of the new domestic developments are ready to move the technological progress now? [2]. Here are some examples of digital technology development. The first is the development of an almost "living" artificial hand of a new generation, which created by firm "MaxBionic". This company produces of advanced bionic prostheses; the company Max Bionic raised 1.5 million rubles through crowd funding and became the most promising innovative company in 2019 in the field of prosthetics. This company produces an ultralight hand, which functions like a real robot arm, and the arm adapts individually to each user. The user can fully control the operation of the prosthesis and even feel the grip power with the help of programmable chips, sensors and a touch control panel, but the price of the prosthesis is quite high and amounts to $\$ 14,000$. Perhaps in the future MaxBionic will be able to reduce the price of the product and start mass production. An industrial medical exoskeleton is a second example. Many companies began testing such devices to reduce the risk of injury to their employees. However, ExoAtlet went further and created an exoskeleton for medical rehabilitation. It helps patients with paralysis of the lower extremities, diseases of the musculoskeletal system or nervous system to move around without assistance. People, who have not yet felt their own legs, get the opportunity to sit down and get up, climb and go down stairs. As a result, their rehabilitation, including psychological, is faster, and the load on clinic staff reduced.

Problems and prospects of innovative technological development depend on the main tasks: efficient use of available resources and technologies; effective state regulation; effective regional resource management system using IT technologies. The largest corporations and joint - stock companies, which get finance of state participation, realize new innovative development programs. This led to an increase in funding for research and development from 268 billion rubles in 2012 to 373 bn. rubles in 2015; the financing grew by 39\%. The growth of extra budgetary funding for research and development increased from 108 billion rubles in 2012 to 140 billion rubles in 2015. In 2015, labor productivity growth amounted to $40 \%$ in nominal terms, and by $15 \%$ in real terms relative to 2012 .

Let us analyze the developed advanced production technologies by the degree of novelty (Table 1).

Analyzing table 1, we observe that the advanced manufacturing technologies that account for design and engineering have a growth dynamics of $11.9 \%$ in 2016 and by $3.7 \%$ in 2017 . The dynamics of decline observed in production, processing and assembly - by $7.1 \%$ in 2016 and by $4.7 \%$ in 2017 compared to 2016. The development of advanced automated transportation of materials and parts, as well as the implementation of automated loading and unloading operations grew by $183 \%$ in 2016 . The production of automated monitoring and control equipment increased by $36.7 \%$ in 2016 compared to 2015, but decreased by $12.3 \%$ in 2017 compared to 2016. The use of advanced production technologies in communications and management increased by $22.3 \%$ in 2016 compared to 2015 , but decreased by $33.5 \%$ in 2017. The development and implementation of production information systems decreased by $1.2 \%$ in 2016 and then decreased by $47 \%$ in 2017 . The use of new production technologies in integrated management and control increased by $32.6 \%$ in 2016 compared to 2015 and by $14.8 \%$ in 2017 compared to 2016 [40]. 
Table 1: Developed Advanced Manufacturing Technology by Degree of Novelty, Units*

\begin{tabular}{|c|c|c|c|c|c|}
\hline & \multirow[b]{2}{*}{$\begin{array}{c}\text { Number of } \\
\text { Technologies (Total) }\end{array}$} & \multicolumn{2}{|c|}{ Included } & \multirow[b]{2}{*}{$\begin{array}{l}\text { Number of Technologies using } \\
\text { Inventions }\end{array}$} & \multirow[b]{2}{*}{$\begin{array}{l}\text { Change } \\
\text { in\% Ratio }\end{array}$} \\
\hline & & $\begin{array}{c}\text { New for } \\
\text { Russia }\end{array}$ & $\begin{array}{c}\text { Fundamentally } \\
\text { New }\end{array}$ & & \\
\hline \multicolumn{6}{|c|}{ Design and Engineering } \\
\hline 2015 & 359 & 323 & 36 & 145 & - \\
\hline 2016 & 402 & 352 & 50 & 149 & $+11,96$ \\
\hline 2017 & 417 & 358 & 59 & 163 & $+3,7$ \\
\hline \multicolumn{6}{|c|}{ Production, Processing and Assembly } \\
\hline 2015 & 548 & 471 & 77 & 247 & - \\
\hline 2016 & 509 & 449 & 60 & 171 & $-7,1$ \\
\hline 2017 & 485 & 417 & 68 & 185 & $-4,7$ \\
\hline \multicolumn{6}{|c|}{ Automated Transportation of Materials and Parts, as well as Automated Loading and Unloading Operations } \\
\hline 2015 & 12 & 10 & 2 & 6 & - \\
\hline 2016 & 34 & 29 & 5 & 9 & $+1,83$ \\
\hline 2017 & 34 & 27 & 7 & 14 & - \\
\hline \multicolumn{6}{|c|}{ Automated Surveillance and / or Control Equipment } \\
\hline 2015 & 117 & 82 & 35 & 53 & - \\
\hline 2016 & 160 & 111 & 49 & 76 & $+36,7$ \\
\hline 2017 & 134 & 107 & 27 & 44 & $-12,25$ \\
\hline \multicolumn{6}{|c|}{ Communication and Management } \\
\hline 2015 & 232 & 218 & 14 & 92 & - \\
\hline 2016 & 285 & 264 & 21 & 81 & $+22,8$ \\
\hline 2017 & 218 & 194 & 24 & 45 & $-33,5$ \\
\hline \multicolumn{6}{|c|}{ Production Information System } \\
\hline 2015 & 84 & 78 & 6 & 33 & - \\
\hline 2016 & 83 & 80 & 3 & 29 & $-1,2$ \\
\hline 2017 & 44 & 44 & - & 11 & -47 \\
\hline \multicolumn{6}{|c|}{ Integrated Management and Control } \\
\hline 2015 & 46 & 41 & 5 & 13 & - \\
\hline 2016 & 61 & 57 & 4 & 12 & $+32,6$ \\
\hline 2017 & 70 & 65 & 5 & 23 & $+14,8$ \\
\hline \multicolumn{6}{|c|}{ Total } \\
\hline 2015 & 1398 & 1223 & 175 & 589 & - \\
\hline 2016 & 1534 & 1342 & 192 & 527 & $+10,2$ \\
\hline 2017 & 1402 & 1212 & 190 & 485 & $-34,6$ \\
\hline
\end{tabular}

*Compiled by the Authors [40]

Consider the internal costs of research and development by type of activity in the process of researching problems in the development of macroeconomic theory and developing theoretical and methodological justifications for scientific and practical innovative development. Noted that labor costs, starting in 2015, are slowly growing: if they were 104.2 billion rubles in 2015, then 114.3 billion rubles in 2017. However, material costs increased significantly by $8.5 \%$, and other costs by $11.4 \%$. The internal costs of research on equipment and capital costs are increasing (Figure 2, Table 2). 


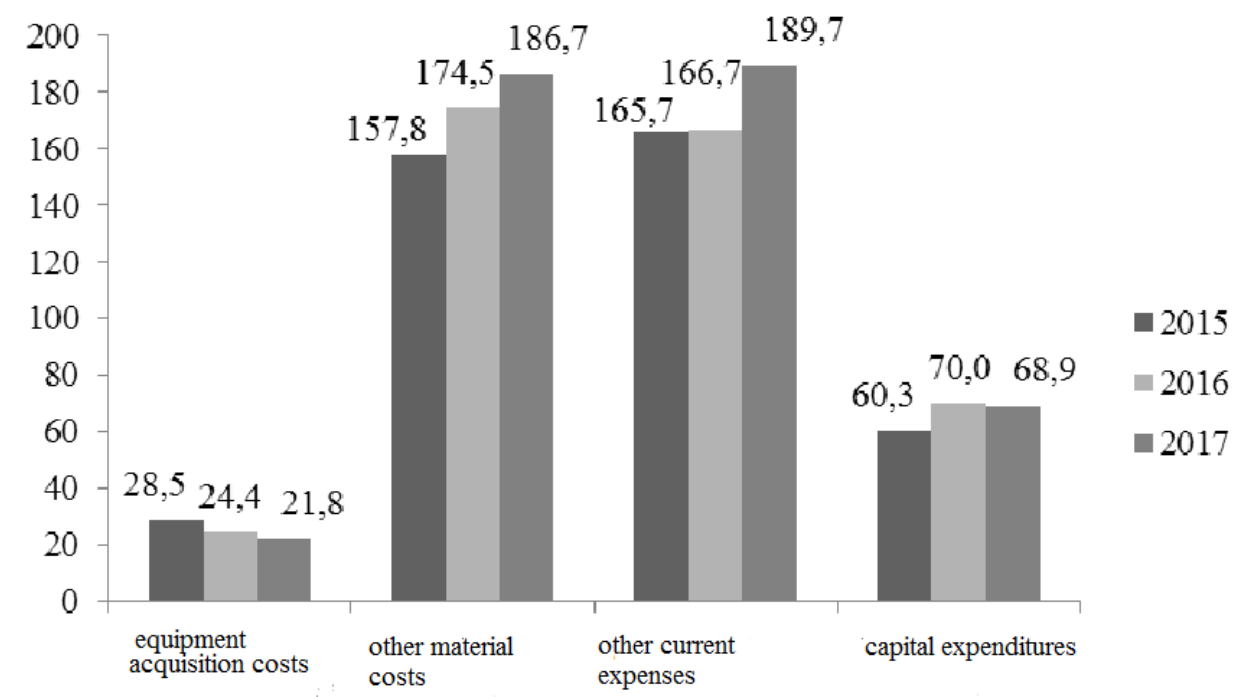

Figure 2: Internal Research and Development Costs by Types of Costs, Billion Rubles [40] Compiled by the Authors.

Table 2: Domestic Expenditure on Research and Development on Socio-Economic Goals, Billion Rubles*

\begin{tabular}{|c|c|c|c|c|}
\hline & 2010 & 2015 & 2016 & 2017 \\
\hline Internal research and development costs & $\mathbf{5 2 3 , 4}$ & $\mathbf{9 1 4 , 7}$ & $\mathbf{9 4 3 , 8}$ & $1019,2(+1,1 \%)$ \\
\hline \multicolumn{5}{|l|}{ including socio-economic goals: } \\
\hline Economic development & 183,1 & 335,5 & 356,7 & $406,0(+14 \%)$ \\
\hline Agriculture, forestry, fishing & 12,1 & 20,5 & 19,8 & $22,2(+12,1 \%)$ \\
\hline Energy production, distribution and management & 19,2 & 28,2 & 28,0 & $29,8(+6,4)$ \\
\hline Industrial production & 126,1 & 247,2 & 267,2 & $310,8(+16,4 \%)$ \\
\hline Building & 5,5 & 4,1 & 4,5 & 4,5 \\
\hline Transport & 12,7 & 28,9 & 28,9 & $29,0(+0,1 \%)$ \\
\hline Communication & 6,7 & 5,1 & 6,8 & $8,3(+18,5 \%)$ \\
\hline Infrastructure and layout of urban and rural settlements & 0,4 & 0,7 & 0,8 & $\begin{array}{c}0,6 \\
(-24 \%)\end{array}$ \\
\hline Services sector & 0,6 & 0,7 & 0,7 & 0,7 \\
\hline Social goals & 25,0 & 47,5 & 53,1 & $\begin{array}{c}51,1 \\
(-3,8 \%) \\
\end{array}$ \\
\hline Environmental protection & 6,0 & 7,7 & 7,0 & $\begin{array}{c}6,2 \\
(-1,4 \%)\end{array}$ \\
\hline Public health & 144 & 27,8 & 33,6 & $\begin{array}{c}30,5 \\
(-8,2 \%)\end{array}$ \\
\hline Social Development and Community Structures & 4,6 & 12,0 & 12,6 & $14,3(+13,5 \%)$ \\
\hline General development of science & 104,3 & 145,2 & 139,6 & $140,0(+0,3 \%)$ \\
\hline Research and use of the Earth and the atmosphere & 19,8 & 43,2 & 35,3 & $41,0(+16,1 \%)$ \\
\hline Peaceful use of space & 27,5 & 57,4 & 46,4 & $\begin{array}{c}41,3 \\
(-10 \%)\end{array}$ \\
\hline Other goals & 163,7 & 285,8 & 312,8 & $339,9(+8,7 \%)$ \\
\hline
\end{tabular}

*Compiled by the authors [40]

The most important conditions for economic growth are investments in research, high technology, technological re-equipment using available resources, including intellectual ones, and a high level of costs for technological innovations.

\section{OVERVIEW OF PROMISING AREAS OF DEVELOPMENT}

The Russian economy is undergoing global changes that form a new economic reality, due to the development of scientific and technological progress, robotics, of digital transformation, innovative and technological development. Domestic company "ThermoLaser" provides services of thermal hardening of parts that comply with global trends. Recently, 
ThermoLaser and the state corporation Rostec for the first time introduced a mobile laser complex for processing parts of various elemental composition and sizes. Using this technology increases the wear resistance of products and extends their service life by several times, and the main advantage of the robotic complex is its mobility. Previously, thermal hardening and laser surfacing required stationary conditions. ThermoLaser's mobile solution is capable of handling even bulky parts that are not transportable. These are, for example, components of the ship's side skin. Each part does not require additional machining, which usually lengthens the process. There is another invention of Russian engineers - a liquid cooling system for data centers. The developers of Inpro Technologies have created the Liquid Cube computing and communication complex, which provides a thermostable mode of operation for data storage and processing systems by immersing the equipment in a dielectric fluid. It is the non-toxic liquid and the method of its circulation in the "cube" that is the main secret of the developers and this invention consumes up to $30 \%$ less energy than when using traditional solutions. The Liquid Cube complex allows you to speed up the process of launching an information infrastructure several times and reduce transaction costs by almost half. The Russian energy-efficient solution allows you to process ever-growing volumes of information without significantly increasing energy consumption. The Volgograd manufacturer Stereotek released the STE520 printer with a share of domestic components of 94.5\%, which considered the world's first desktop 5D printer. This does not mean that the device can print time and sensations - just it prints in two more planes instead of three coordinate axes $\mathrm{X}, \mathrm{Y}$ and $\mathrm{Z}$.

The innovative technology of additive five-axis printing allows you to create more durable products than with conventional 3D printing. According to the creators, the print quality with 5Dtech technology does not depend on the shape of the parts, and the dimensions of the products are temporarily limited: $15 \times 15 \times 15 \mathrm{~cm}$. 5Dtech technology won the AllRussian S7 Startup Challenge from the Skolkovo Foundation, won the Battle of Startups competition, and also won the Innovative Project of the Year nomination at the 3D Print Expo 2019; and is of interest to aviation and defense enterprises.

Another promising project using 3D printing (but not only it) intends for a children's audience. ROBBO is a free educational robotics project on open source software and hardware. In fact, this robotic constructor allows you to assemble your own robot and write the first program for it. In addition, the company opened robotic and free programming clubs "ROBBO Clubs", where children learn to create robots "from scratch" using 3D modeling and 3D printing technologies, as well as write programs to manage them. Currently, ROBBO teaches 50 thousand children in more than 200 schools and 110 sections in 16 countries: Russia, Finland, Thailand, the UK, USA, Spain, Vietnam, China, Kazakhstan, Belarus, Tajikistan, Israel, Germany, Italy, and now in Japan. Recently, the government of Fukuoka invited ROBBO to open ROBBO Japan after winning the project in the Russian-Japanese technology project competition Fukuoka Startup Day and successfully testing the company's products in schools in the country. Technological policy replaces the innovative one and becomes digital, state corporations appointed responsible for technological breakthroughs, and the competitive private medium-sized technology business is again out of state attention [43].

2019 year completed a whole stage in the construction of a national innovation system. The main content of this stage was the creation of a variety of infrastructures and tools that stimulate the development of innovation. The main content of this stage was the creation of a variety of infrastructures and tools that stimulate the development of innovation. This ideology was down in the Basic Document, which determined the nature of this stage - these are the Innovative Russia strategy adopted in 2011. Technology parks and techno valleys, open economic zones and clusters, agencies and funds, venture funds and accelerators, educational and consulting programs created (and be created). Methods for the 
development of innovative activity in large companies (primarily with state participation) were prepared, and much more done that was necessary and useful to support innovative activity. A variety of development teams, startups and simply innovative and active companies, regardless of the subject of the innovations they develop, will contact the infrastructure with their projects, receive the necessary support, and then implement their developments in a free competitive market.

\section{TECHNOLOGY POLICY REPLACES INNOVATION}

Innovative activity began to produce results in various forms: projects arose, startups were created, a number of companies were able to create quite successful businesses based on original developments. Russia bears domestic current expenditures on research and development by type of work and field of science (Table 3).

Table 3: Domestic Current Expenditure on Research and Development by Type of Work and Field of Science, Billion Rubles *

\begin{tabular}{|c|c|c|c|c|c|c|c|}
\hline & Total & Natural & Technical & Medical & Agricultural & Public & Humanities \\
\hline \multicolumn{7}{|c|}{ Basic Research } \\
\hline 2015 & 132,1 & 75,1 & 20,6 & 9,9 & 8,1 & 9,2 & 9,3 \\
\hline 2016 & 132,6 & 75,6 & 20,0 & 10,0 & 8,1 & 9,5 & 9,4 \\
\hline 2017 & 141,3 & 77,4 & 23,8 & 11,4 & 8,2 & 11,0 & 9,5 \\
\hline Total & 406,0 & 228,1 & 64,4 & 31,3 & 24,4 & 29,7 & 28,2 \\
\hline \multicolumn{7}{|c|}{ Applied Research } \\
\hline 2015 & 169,7 & 43,5 & 90,4 & 16,6 & 3,7 & 12,2 & 3,2 \\
\hline 2016 & 181,2 & 42,2 & 99,0 & 20,8 & 4,0 & 12,6 & 2,5 \\
\hline 2017 & 172,5 & 40,1 & 91,7 & 20,6 & 4,4 & 13,0 & 2,8 \\
\hline Total & 530,1 & 125,8 & 281,1 & 58,0 & 12,1 & 37,8 & 8,5 \\
\hline \multicolumn{7}{|c|}{ Working-Out } \\
\hline 2015 & 552,6 & 30,4 & 513,2 & 3,3 & 1,9 & 2,6 & 1,1 \\
\hline 2016 & 560,1 & 32,2 & 520,4 & 3,2 & 1,8 & 1,7 & 0,7 \\
\hline 2017 & 636,4 & 37,7 & 591,0 & 3,8 & 1,5 & 1,7 & 0,6 \\
\hline Total & 1749,1 & 100,3 & 1724,9 & 10,3 & 5,2 & 6,0 & 2,4 \\
\hline Total by Directions & $\mathbf{2 6 8 5 , 2}$ & $\mathbf{4 5 4 , 2}$ & $\mathbf{2 0 7 0 , 4}$ & $\mathbf{9 9 , 6}$ & $\mathbf{4 1 , 7}$ & $\mathbf{7 3 , 5}$ & $\mathbf{3 9 , 1}$ \\
\hline
\end{tabular}

*Compiled by the authors [40]

However, all this was obviously not on the scale to become an economically significant factor in the country's development, to change the structure of the economy and provide a technological breakthrough. Perhaps the Russian innovation strategy does not have enough time and patience for the appearance of effects of the necessary scale; in some bottlenecks, structural and institutional approaches conflict with the changed general socio-economic vector of the country's development; key performance indicators of innovative development of Russia have not yet achieved. However, it is not even a matter of disrupting formal indicators - the ideology of betting on innovation as an important factor in economic growth has turned out to be worthless. The initiatives in innovations become less; one of the last attempts to launch a large-scale project in this ideological discourse was the Technology Leadership program, which was born in the summer of 2018 in the relevant department of the Ministry of Economic Development of Russia. However, it also did not find support in the government and died quietly in early 2019 of the year. Actually, the past year started with this fiasco. It is not even a matter of disrupting formal indicators - the ideology of betting on innovation, as an important factor in economic growth, has proven to be worthless.

At the same time, another trend began to gain strength since the middle of 2018. These were digitalization and end-to-end technology initiatives [44]. The main directions for the development of end-to-end digital technologies were identified in accordance with the May decree of the President on national goals and strategic objectives for the 
development of the Russian Federation (first there were nine, then seven). In March 2019, as part of the federal project Digital Technologies, tenders announced for writing roadmaps for each of these areas. In July, the results summed up, Sberbank became responsible for artificial intelligence, Rostec for quantum sensors, block chain and the Internet of things, Rostelecom and Rostec for wireless communication technologies (5G), and Rosatom for quantum computing, and Russian Railways - for quantum communications.

In fact, what arose as an attempt to formulate a "technological policy with Russian specifics" arose. Even though today it focuses only on the topic of digital technology, but this is only the beginning. Several years ago, in the state political vocabulary there were no concepts of technological and industrial policies that would determine what technologies and industries we develop, in what way, what we want to get out [45, 2]. Already, experts recognize that the formation of approaches to the implementation of the national project "Digital Technologies" strongly distinguishes it from other national projects in terms of originality, flexibility of approaches and willingness to transform them as an understanding of the processes takes place. Having worked out the implementation of such policies using the example of "numbers", in the future it will be possible to think about technology policy in other sectors and in other areas [46, 47]. Vladimir Vladimirovich Putin said at the International Economic Forum about technological solutions as the basis for further development of the country. Moreover, not only to increase the rate of economic growth, but also to reform the entire government system: "It is necessary to ensure the transformation of the public administration system based on digital technologies in the shortest possible time, thus dramatically improving the effectiveness of all levels of government, the speed and quality of decision-making". The President also called (and repeated this thesis several times in different audiences) the mastery of artificial intelligence the main means of gaining global hegemony in the future.

An attempt to implement an innovative policy before technological and industrial policies was initially not too thorough and doomed to local results [48]. It built on the rather theoretical ideas about what needs to done, by analogy with other countries, and not from the real needs of the national economy and industry. Therefore, today you should not mourn the actual completion of the "innovation policy" as an object of management - we will definitely return to it in a few years, having gone through all the intermediate stages and better understanding what needs to reflect in it.

\section{DISCUSSION}

The question of the correct choice of the priorities of innovative technological development, which exclusively related to the topic of high technology and digitalization of the economy, remains fair. The digitalization, which is gaining wide distribution today, mainly associated with the diffusion of the basic technologies of the previous technological wave (information) in the real sector of the economy, and not with the introduction of fundamentally new technological solutions. In addition, it is impossible to make this breakthrough only on the digital technologies, without the corresponding development of the high-tech technologies themselves associated with materials, energy, cognitive technologies, and biotechnologies Therefore, when implementing a new innovation and technology policy, it would be worth thinking about expanding the directions of its implementation. Another and important change in the construction of an innovative technological paradigm is a clearly defined installation of the country's political leadership to bet on large, primarily state-controlled, corporations in the implementation of the emerging technological policy.. They become the basis, the center of coordination of activity of all other players. This was stated by Vladimir Putin in his speech at the SPIEF in June 2019: "I offer our companies with state participation, as well as leading Russian private companies, to 
become the main partners of the state in the development of cross-cutting scientific and technological areas: this, as I have already said, is artificial intelligence and other digital technologies."

At the beginning of 2020, it decided to transfer the preparation of roadmaps for the development of end-to-end technologies from the Ministry of Digital Development to the largest state-owned companies. A particularly clear new configuration of the created innovation system announced at the end of the year as part of the Global Technology Leadership Week in Sochi, where these roadmaps passed stress tests. Apparently, this system will look as follows. State corporations that responsible for the technological area allocated to them by the state become the coordinators of the activity of all other players who are ready to participate in its development (development institutions, companies, universities, research institutes, individual citizens). Each state corporation will create a competence center, which will responsible for the development of the technological initiative. This whole system, uniting the participants in the development of a specific technological area, is an ecosystem. The question remains of the correct choice of priorities for innovative technological development, which today exclusively related to the topic of digitalization of the economy.

\section{CONCLUSIONS}

A new paradigm of economic development forms in the article from the perspective of macroeconomic theory in the context of modern accelerated development of the scientific and technological progress of the world economy. These processes in the Russian economy are based on the strategy of innovative activity and innovative development, the introduction of new high technology, constant monitoring of markets for goods and services, the search for future transformations that can find unexpected solutions the first.

We exanimated the scientific discussion that unfolded in the Russian scientific literature regarding the formation of a new innovative paradigm. We determined that the state innovation policy to mobilize the resource potential to ensure future socio-economic development, creating conditions for innovative transformation through the introduction of high technology technologies, which are based on cognitive, information and communication technologies, and forms a new development path for the sixth technological structure.

We believe that at the present stage of innovative development, effective mechanisms are being created in the system of innovative technological development, a new paradigm is being formed that closes on the totality of financial institutions linking the system of these links, which, according to many economists, is not fully understood. The positive results of this debate go deeper into the understanding of the macroeconomic policy of the state; determine the qualitative changes in the system of institutional foundations and timely, high-quality transformational processes in the public administration system. The desire of the Russian economy to get a high effect depends directly on the priorities of the chosen directions of state policy, the vector of economic theory based on the revealed new laws of socio-economic development and practical experience.

\section{REFERENCES}

1. Ilyashenko, V.V. The relationship of economic theory and politics of the Russian state. Journal of New Economy 20(5) (2019) 5-22. DOI: 10.29141/2658-5081-2019-20-5-1

2. Dyachenko, O.V. Definition of the category of "digital economy" in foreign and domestic economic science. The economic revival of Russia 1 (2019) 86-98. 
3. Ilyashenko, V.V. Macroeconomic and microeconomic aspects of inflation in the transforming economy of Russia. Publishing House of the Ural State Economic University, Ekaterinburg, 2006, 342 p.

4. Mironov, V. About imaginary and real threats. Expert 25 (2001) 50.

5. Bhatia, Ketki K., and Mayank. Trivedi. "MOOCs: Paradigm shift for libraries." International Journal of Library \& Educational Science 4.4 (2015): 67-80.

6. Silin, Y.P., Animitsa, E.G., Novikova, N.V. Theories of economic growth and economic cycle in the study of regional processes of new industrialization. Journal of New Economy 20(2) (2019) 5-29. DOI: 10.29141/20731019-2019-20-2-1

7. Harrod, R. To the theory of economic dynamics. Keynesian classics: in 2 volumes. Vol. 1. Economics, Moscow, 1997, pp. 129131.

8. Sannikova, T.D. Institutional and resource constraints on solving the Transition to the digital economy. Issues of innovative economics 9(3) (2019) 633-646. DOI: 18334/vinec.9.3.41059

9. Lavrischeva, E. M. "The Scientific basis of software engineering." International Journal of Applied and Natural Sciences 7.5 (2018): 15-32.

10. Andieva, E.Yu., Filchakova, V.D. Digital Economy of the Future, Industry 4.0. Applied mathematics and fundamental informatics 3 (2016) 214-218.

11. Yudina, T.N. Understanding the digital economy. Theoretical Economics 3 (2016) 12-16.

12. Popova, L.V., Korostelkina, I.A., Detkova, E.G. Study of the modern paradigm of innovative development of the national economy. Bulletin of Omsk State University. Series: Economics 4 (2018) 44-55.

13. Buch, C.M., Kleinert, J., Toubal, F. The distance puzzle: On the interpretation of the distance coefficient in gravity equations. Economics Letters 83(3) (2004) 293-298.

14. Schumpeter, J. Theory of Economic Development: A study of entrepreneurial profit, capital, credit, and the business cycle. Progress, Moscow, 1982, $455 \mathrm{p}$.

15. Bergstrand, J.H. The generalized gravity equation, monopolistic competition, and the factor-proportions theory in international trade. Review of Economics and Statistics 71(1) (1989) 143-153.

16. Anderson, J.E. Theoretical foundation for the gravity equation. American Economic Review 69(1) (1979) $106-116$.

17. Anderson, J.E. The gravity model. Annual Review of Economics 3(1) (2011) 133-160.

18. Burkaltseva, D., Vorobyov, Yu., Borsh, L., Gerasimova, S., Chepurko, V. Structural modelling the system of ensuring the economic security of the complex territorial socio-economic system of the eurasec. International Journal of Applied Business and Economic Research 14(9) (2016) 5683-5704.

19. Borsch, L., Burkaltseva, D., Vorobyov, Yu., Vorobyova, E., Chepurko, V. Dichotomy or unification of contrasts of the market and capitalism: Forecast and plan (part 1). International Journal of Economic Research 13(9) (2016) 3775-3787.

20. Borsch, L., Burkaltseva, D., Vorobyov, Yu., Vorobyeva, E., Chepurko, V. Dichotomy or unification of contrasts of the market and capitalism: Forecast and plan (part 2). International Journal of Economic Research 13(9) (2016) 3789-3801.

21. Burkaltseva, D.D., Tsohla, S.Yu., Guk, O.A., Borovskaia, L.V., Bondar, A.P. Basic forms of institutional changes of economy in Russia. International Journal of Applied Business and Economic Research 14(15) (2016) 11137-11152. 
22. Burkaltseva, D.D., Voronin, I.N., Lisitsky, A.M., Mazur, N.M., Guk, O.A. Assessing the Effects of Investments Into Innovative Activity as a Regional Competitiveness Factor. International Journal of Applied Business and Economic Research 15(8) (2017) 11-27.

23. Dubey, A. K., et al. "SPSUC: slice, pattern \& style of ubiquitous computing." International Journal of Computer Science Engineering, and Information Technology Research (IJCSEITR) ISSN (P): 2249-6831.

24. Burkaltseva, D.D., Borsch, L.M., Blazhevich, O.G., Frolova, E.E., Labonin, I.V. Financial and economic security of business as a primary element in the economic system. Revista Espacios 38(33) (2017) 3.

25. Sivash, O.S., Burkaltseva, D.D., Ushakov, D.S. Activization of Investment Process in the Agrarian Sector. International Journal of Ecology and Development 32(4) (2017) 169-182.

26. Varghese, Mary George, and Shefali Pandya. "A Study on the Effectiveness of Brain-Based-Learning of Students of Secondary Level on their Academic Achievement in Biology, Study Habits and Stress." IASET: International Journal of Humanities and Social Sciences (IJHSS) ISSN (P) 2319 (2016).

27. Vorobyov, Yu.N., Burkaltseva, D.D., Kovalyova, I.N., Borsch, L.M., Gerasimova, S.V. Sustainable Development of the Regional Economy: Indicators, Analysis, Systematization. Journal of Advanced Research in Law and Economics 9(2) (2018) 729-739.

28. Burkaltseva, D.D, Betskov, A.V., Kilyaskhanov, H.Sh., Demin, G.I., Grischenko, L.L., Timoshenko, O.E., Tyulin, A.S. Psychological Features of Cybercriminal Behavior in Committing Financial Crimes under Conditions of Digital Transformation of Socioeconomic Systems. Opción 34(85) (2018) 1642-1653.

29. Burkaltseva, D.D., Betskov, A.V., Kilyaskhanov, H.Sh., Demin, G.I., Grischenko, L.L., Timoshenko, O.E., Tyulin, A.S. Psychology of Criminal In Conditions Of Socioeconomic System Transformation. Opcion 35(SI19) (2019) 2872-2882.

30. Klimchuk, S.V., Sivash, O.S., Burkaltseva, D.D., Nekhaychuk, D.V, Gurova, V.A., Kilyaskhanov, H.Sh., Zotova, S.A. Time Lag in the System of Financial Transformations. International Journal of Recent Technology and Engineering 8(3) (2019) 40-45. DOI: 10.35940/ijrte.C3869.098319

31. Gerasimova, S., Burkaltseva, D., Borsch, L., Apatova, N., Vorobyova, E., Zharova, A., Ivanov, S., Zaytseva, I. Multi-level transformation processes: digital technologies in the economy. International Journal of Innovative Technology and Exploring Engineering 8(12) (2019) 419-425.

32. Nalivaychenko, E.V., Kirilchuk, S.P., Apatova, N.V., Skorobogatova, T.N., Boychenko, O.V. Managing intellectual property in information economy. Astra Salvensis 6 (2018) 711-721.

33. Apatova, N.V., Boychenko, O.V., Nekrasova, T.P., Malkov, S.V. Virtual telecommunication enterprises and their risk assessment. Lecture Notes in Computer Science 10531 LNCS (2017) 326-336.

34. Varnaliy, Z., Onishchenko, S., Masliy, A. Threat prevention mechanisms of Ukraine`s economic security. Economic AnnalsXXI 159(5-6) (2016) 20-24.

35. Pshenichnikov, V.V., Babkin, A.V. Digital money as a product of the development of information and telecommunication technologies. In: Proceedings of the 2017 International Conference "Quality Management, Transport and Information Security, Information Technologies”. Saint-Petersburg, Russia, September 24-30, 2017. St. Petersburg State Electrotechnical University LETI named after V.I. Ulyanov (Lenin), St. Petersburg, 2017, pp. 259-265.

36. Dudin, M.N. Public and business regulation as the basis of self-organization and evolution of the national innovation system. The Journal of Internet Banking and Commerce 21(S4) (2016) e101. 
37. Kosten, D. Bitcoin Mission Statement. Or What Does It Mean Sharing Economy and Distributed Trust? 2015. Retrieved from https://papers.ssrn.com/sol3/papers.cfm?abstract_id=2684256

38. Korobeynikova, O.M., Korobeynikov, D.A., Popova, L.V. Scenarios of digital innovation of the payment market in Russia. In: Advances in Social Science, Education and Humanities Research. Vol. 240. Proceedings of the 2nd International Scientific conference on New Industrialization: Global, national, regional dimension (SICNI 2018). Saint-Petersburg, Russia, October 26-27, 2018. Atlantis Press, St. Petersburg, 2018, pp. 174-178. https://www.atlantis-press.com/proceedings/sicni-18/55911830

39. Semenyuk, O., Abdrashitova, T., Beloussova, E., Nechay, N., Listkov, V., Kurbatova, V., Niyazbekova, S. The influence of ecology and economic factors on eco-architecture and the design of energy efficient buildings. World Transactions on Engineering and Technology Education 16(2) (2018) 186-192.

40. Niyazbekova, Sh.U., Grekov, I.E., Blokhina, T.K. The influence of macroeconomic factors to the dynamics of stock exchange in the Republic of Kazakhstan. Economy of region 12(4) (2016) 1263-1273. DOI: 10.17059/2016-4-26

41. Kuleshova, G.I. Territories in the digital economy: theses for a new discourse in professional discussion. Urban planning 4 (2017) 11-16.

42. Surinov, A.E. Digital economy: challenges for Russian statistics. Statistics issues 25(3) (2018) 3-14.

43. Yakutin, Yu.V. The Russian Economy: A Digital Transformation Strategy (Toward Constructive Criticism of the Government's Digital Economy of the Russian Federation Program). Management and business administration 4 (2017) 25-72.

44. Federal Service of State Statistics. Russia in 2018 numbers. 2018, 499 p.

45. Borsch, L.M. Modernization of the Economy: technology vs human. Bulletin of the Ural State Economic University 19(3) (2018) 42-55.

46. Borsch, L.M., Gerasimova, S.V., Tyulin, A.S. On issues of economic transformation and modernization of technological processes in Russia. Creative economy 6 (2018) 717-732. DOI: 10.18334/ce.12.6.39206

47. Blanutsa, V.I., Cherepanov, K.A. Regional information flows: existing and new approaches to geographical study. Regional Research of Russia 9(1) (2019) 97-106.

48. Filkevich, I.A., Igumnov, O.A. The digital economy in Russia: global trends and Russian opportunities. Ideas and innovations 6(2) (2018) 45-58.

49. Schukina, A.Ya., Vasiliev, A.N., Orlov, Y.V. Formational and civilizational approach to socio-economic development: a common understanding and their relationship. Bulletin of VUiT 23 (2011) 106-109.

50. Makogonova, N.V. Risks of implementing the state program "Digital Economy of the Russian Federation". Management sciences in the modern world 1(1) (2018) 569-576.

51. Petrov, A.A. Digital Economy: Russia's Challenge in Global Markets. Trade Policy 3 (2017) 46-74.

52. Saibel, N.Yu., Kosarev, A.S. Transformation factors of the socio-economic system. International Research Journal 12(66) (2017) Part 3 58-63. 